\title{
Rapid Invasion Despite Lack of Genetic Variation in the Erythrina Gall Wasp (Quadrastichus erythrinae Kim) ${ }^{1}$
}

\author{
Daniel Rubinoff, ${ }^{2,5}$ Brenden S. Holland, ${ }^{3}$ Alexandra Shibata, ${ }^{2}$ Russell H. Messing, ${ }^{4}$ \\ and Mark G. Wright ${ }^{2}$
}

\begin{abstract}
The erythrina gall wasp, Quadrastichus erythrinae Kim, has recently and rapidly invaded a broad swath of the tropical and subtropical Pacific Basin, causing severe damage to most species of coral trees (Erythrina spp.). This small (length $\sim 1.5 \mathrm{~mm}$ ) wasp attacks the photosynthetic tissue (leaves, buds, stems, flowers) of ornamental and native Erythrina, often killing the trees. This invasion poses an immediate extinction threat to native Erythrina spp. throughout Asia, Australia, and a number of Pacific archipelagos, including Hawai'i, where populations of the endemic E. sandwicensis have been devastated. Although this pest is known to occur naturally in East Africa, the precise geographic origin of the invasions remains unknown. In this study, 1,623 base pairs of mitochondrial (cytochrome $c$ oxidase subunit I) and nuclear DNA (elongation factor alpha) were used to confirm systematic identity and to examine genetic divergence among invasive populations from Hawai'i, Guam, American Samoa, Japan, Singapore, Taiwan, and China. Samples from all invasive populations included in our study showed a complete lack of genetic diversity. Molecular findings confirm that a single species, Q. erythrinae, is involved in this dramatic, recent range expansion and that introductions may have been associated with population bottlenecks that have reduced genetic diversity in populations sampled. Although reductions in genetic diversity are generally considered detrimental to fitness, this study provides an example of invasion success despite a lack of detectable genetic variation. The monomorphic genetic pattern observed also suggests that $Q$. erythrinae initially may have been introduced to one location, and this invasive population may have subsequently served as a source for additional secondary invasions by unknown introduction vectors.
\end{abstract}

1 This research was supported in part by a grant from the State of Hawai' $i$ Invasive Species Council, the USDA-CSREES-TSTAR program, and the Tri-Isle Research and Development. B.S.H. was supported by a grant from the U.S. Army Natural Resources Division during preparation of the manuscript. Manuscript accepted 27 April 2009.

${ }^{2}$ Department of Plant and Environmental Protection Sciences, 310 Gilmore Hall, 3050 Maile Way, University of Hawai'i at Mānoa, Honolulu, Hawai'i 96822.

${ }^{3}$ Center for Conservation Research and Training, 3050 Maile Way, University of Hawai'i at Mānoa, Honolulu, Hawai'i 96822.

${ }^{4}$ Kaua'i Agricultural Research Center, 7370 Kuamo'o Road, Kapa'a, Hawai'i 96746.

${ }^{5}$ Corresponding author: (e-mail: rubinoff@hawaii .edu).

Pacific Science (2010), vol. 64, no. 1:23-31

doi: 10.2984/64.1.023

(C) 2010 by University of Hawai'i Press

All rights reserved
Coral trees (Erythrina spp., Leguminosae/ Fabaceae) are a widespread and diverse genus of trees with approximately 110 species (Mabberly 1987), with a global tropical distribution. Their range includes not only continental endemic species across Africa, Australia, and South America but also endemic species in the islands of Hawai' $i$, the South Pacific, Micronesia, and the Caribbean, where they are important components of native ecosystems. Some Erythrina species have been widely planted as ornamental trees, prized for their dramatic, seasonal flowers and variegated leaves, and other species are important agricultural resources serving as windbreaks, shade trees for crops (macadamia, coffee, cocoa), living fences, and fodder. In the Hawaiian Islands, the endemic coral tree, or wiliwili, Erythina sandwicensis, histori- 
cally has been an important component of cultural activities and mythology; lei were made from its flowers and seeds, wood and bark were used for various purposes including canoe building. The wiliwili tree is one of Hawai'i's few deciduous endemic trees and grows to heights of over $13 \mathrm{~m}$, preferring dry forests of the leeward slopes on all of the main islands, from sea level to an elevation of $600 \mathrm{~m}$ (Wagner et al. 1990).

Damage to Erythrina trees due to an invasive wasp was first documented in 2003, when ornamental trees in the Mascarene Islands and southern Taiwan (Yang et al. 2004) were infested and defoliated by a then-unknown species of eulophid wasp. Within a year, the wasp had spread throughout Taiwan and reached Singapore and by 2005 was documented in Hong Kong and mainland China ( $\mathrm{Li}$ et al. 2006) and was reported on $\mathrm{O}^{\prime} \mathrm{ahu}$ in the Hawaiian Islands in April of that year (Gramling 2005). Within 6 weeks of its arrival in Hawai'i, the wasp had spread over $500 \mathrm{~km}$, throughout the high islands. In 2004 the wasp was described as Quadrastichus erythrinae Kim, the erythrina gall wasp (Kim et al. 2004), from specimens collected in Singapore, Mauritius, and Réunion (regions with no native Erythrina). In a span of about 2 yr, the erythrina gall wasp had spread across a tropical swath from Hawai'i to India, a distance of more than $12,546 \mathrm{~km}$, much of it across open ocean (Heu et al. 2005, Schmaedick et al. 2006). The erythrina gall wasp has infested and often essentially eliminated most trees of all species of Erythrina in those regions, causing a horticultural disaster. In 2006, the erythrina gall wasp moved into the tropical Atlantic, reaching Florida, and appears poised to spread into the Caribbean and South America, where there are large numbers of endemic Erythrina species naive to leaf-galling wasps.

The erythrina gall wasp lays eggs in leaves, petioles, young shoots, and stems, forming galls in green plant tissue, completely deforming the trees and threatening the plants' survival. Larvae of this small $(1.5 \mathrm{~mm})$, phytophagous wasp hatch within the galls and feed. During severe infestations, even large mature trees are killed.
By killing off spectacular ornamental specimens, agriculturally valuable plantings, and the endemic E. sandwicensis, the erythrina gall wasp has already caused substantial impacts to Hawaiian tourism, agriculture, and native ecosystems. This pattern is typical everywhere the wasp has spread.

Before the 2003 invasions, the erythrina gall wasp was unknown, and there were no other gall-forming wasps recorded from any Erythrina across the Indian and Pacific oceans, although it is well known that subSaharan Africa hosts a diversity of gall wasps on Erythrina. Examination of host-plant relationships of $Q$. erythrinae (using 71 different Erythrina species) confirms an African origin for the wasp (Messing et al. in press).

Despite the widespread ecological and economic damage caused by invasive species, biological and genetic factors contributing to success of invaders often remain unclear. Although a number of studies investigating levels of genetic polymorphism in invasive populations have demonstrated decreases in genetic diversity relative to native populations (Colautti et al. 2005, Lindholm et al. 2005, Chandler et al. 2008), there are also many examples where population genetic diversity was not substantially decreased (Holland 2001, Hassan et al. 2003) or, despite decreases, invasions proceeded apparently undeterred by any perceivable decrease in fitness (Tsutsui and Suarez 2003, Le Roux et al. 2007, Chandler et al. 2008).

A single species of erythrina gall wasp has recently been documented as responsible for this devastating invasion, but systematic identity of the wasp has been based solely on morphology and behavior, and questions regarding the relationships among the populations, the number of species involved, the potential for the presence of cryptic species, the number of introductions, the geographic source region, and the genetic diversity of these rapidly invading populations remain unanswered. Tung et al. (2009) found no genetic variation in a mitochondrial and nuclear gene in 47 individuals of the erythrina gall wasp from Mauritius, where it was first recorded, and populations in Singapore and Taiwan, but this result needs to be confirmed 
across the broader geographic range of the invasion and with more extensive sampling to understand the role of genetic diversity in promoting the erythrina gall wasp's explosive invasion.

Using both nuclear and mitochondrial DNA markers, we sequenced samples of the erythrina gall wasp from across much of its recently invaded range in the Pacific Basin, including American Samoa, China, Guam, Hawai'i, Japan, Singapore, and Taiwan to address the following questions: Is the invasive erythrina gall wasp a single species, or have multiple gall wasps with similar ecology caused this invasion? If the invasion is a single species, how many times was it introduced and from how many source populations? Is there evidence for population bottlenecks (i.e., indicated by lack of genetic diversity across populations)? The answers to these questions apply directly to future efforts to control the erythrina gall wasp and to prevent future introductions of additional gall wasp species that may cause additional damage.

\section{MATERIALS AND METHODS}

\section{Sampling}

We acquired samples of the erythrina gall wasp from much of its invasive range across $7,840 \mathrm{~km}$ of the tropical Pacific Basin (Figure 1, Table 1). Outgroups included unidentified erythrina gall wasp species collected in South Africa. Specimens were placed into 95\% alcohol in the field and transported to our laboratory at the University of Hawai'i. Superficial morphological examination of wasps was conducted for all specimens. Target gene fragments were selected for their rapid substitution rates and to take advantage of the strengths of both nuclear and mitochondrial markers and avoid potential bias due to use of only a single character partition (Rubinoff and Holland 2005).

\section{DNA Extraction, PCR Amplification, and Sequencing}

Genomic DNAs were extracted according to the manufacturer's protocol using QIAGEN
DNeasy nucleic acid extraction kits (QIAGEN, Valencia, California). DNAs were eluted in deionized autoclaved water and stored at $-80^{\circ} \mathrm{C}$. Polymerase chain reaction (PCR) was performed using a PTC-200 thermocycler (MJ Research, Reno, Nevada). Cytochrome $c$ oxidase I (COI) primer sequences used were as follows: gene regions were PCR amplified and sequenced using the following primers: COI, Jerry (5' CAA CAT TTA TTT TGA TTT TTT GG) and Pat $\left(5^{\prime}\right.$ ATC CAT TAC ATA TAA TCT GCC ATA); nuclear elongation factor (EF1- $\alpha$ ), Oscar (5' GGC CCA AGG AAA TGG GCA AGG G) and Bosie (5' CCG GCG ACG TAA CCA CGA CGC). Both COI and EF1- $\alpha$ primers amplified the target fragment consistently under the following PCR conditions: $2 \mathrm{~min}$ at $92^{\circ} \mathrm{C}, 30$ cycles of $94^{\circ} \mathrm{C}$ for $30 \mathrm{sec}, 50^{\circ} \mathrm{C}$ for $30 \mathrm{sec}$, and $72^{\circ} \mathrm{C}$ for 45 sec, with a final $72^{\circ} \mathrm{C}$ extension for $7 \mathrm{~min}$. PCR-amplified DNA fragments were purified with QIAquick spin columns (QIAGEN), according to the manufacturer's protocol, then checked via agarose gel electrophoresis. Forward and reverse strands were cyclesequenced using the PCR primers. ABI Prism DYE Terminator Cycle Sequencing Reaction Kits in a thermal cycler (Perkin-Elmer 9700) were used to generate single-stranded products, and sequences were determined using an automated sequencer (ABI 377, PE Biosystems, Foster City, California).

\section{Phylogeny Reconstruction}

In cases where different methods give similar or identical topologies, confidence is increased that the results are representative of the evolutionary history of the sequences composing the data set (Cunningham 1997). Therefore a variety of approaches was used for phylogeny reconstruction, including maximum parsimony (MP), maximum likelihood (ML), and minimum evolution (ME) with various models of molecular evolution (e.g., Jukes-Cantor, uncorrected "P," Tajima-Nei, Kimura 2-parameter, Tamura-Nei, Kimura 3-parameter). Statistical support was assessed with 1,000 bootstrap replicates for ML, MP, and ME methods (Felsenstein 1985). Trees 


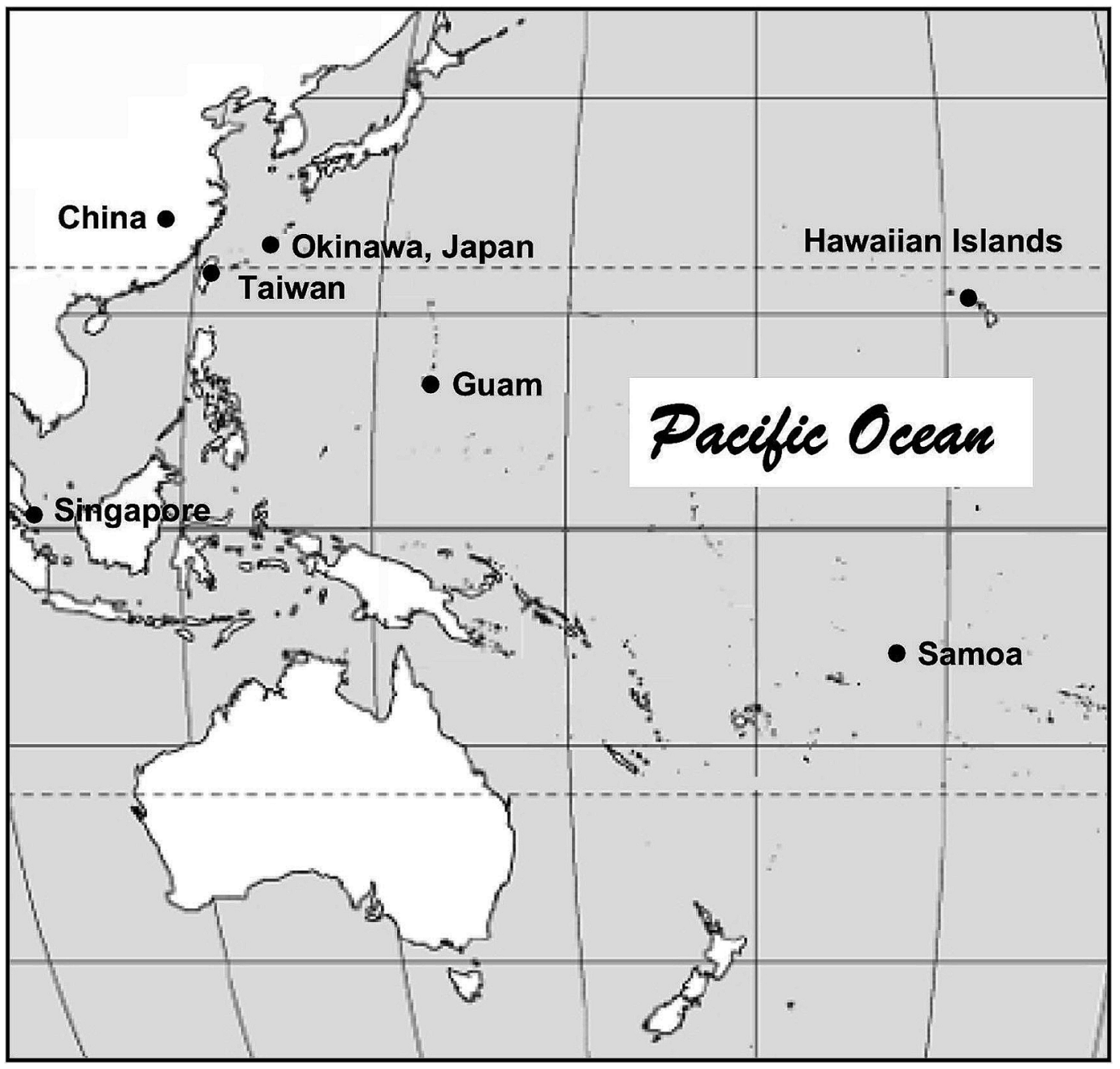

Figure 1. Map of the western Pacific Ocean showing sampling localities.

were rooted with multiple outgroups, and resultant topologies were compared for the three approaches (Figures 2 and 3).

\section{RESULTS}

Erythrina gall wasp samples from Japan, Taiwan, China, and islands spanning approximately 7,840 km of the Pacific Basin (Figure 1) were monomorphic for both loci sequenced, with a single COI haplotype and a single genotype for the nuclear gene EF1- $\alpha$
(Figures 2 and 3). After editing and alignment, sequenced gene fragments obtained were 821 base pairs for COI and 802 base pairs for the EF1- $\alpha$ gene. Bootstrap support based on 1,000 replicates for minimum evolution/maximum likelihood/maximum parsimony (ME/ML/MP) was $100 \%$ for each optimality criterion. Although we had planned to use statistical parsimony to reconstruct haplotype networks and analysis of molecular variance to elucidate population genetic partitioning, none of these ap- 
TABLE 1

Sampling Localities, GeneBank Accession Numbers

\begin{tabular}{|c|c|c|c|c|c|}
\hline $\begin{array}{l}\text { Sample Codes } \\
\text { (Species, if not } \\
\text { Q. erythrinae) }\end{array}$ & $\begin{array}{l}\text { Collection } \\
\text { Date }\end{array}$ & Source & Host Species & Collector & $\begin{array}{c}\text { GeneBank } \\
\text { Accession No. } \\
(\mathrm{COI} / \mathrm{EF} 1-\alpha)\end{array}$ \\
\hline $39-47$ & January 2006 & $\begin{array}{l}\text { University of } \\
\text { Hawai'i at Mānoa } \\
\text { campus, O'ahu, } \\
\text { Hawai'i }\end{array}$ & Erythrina spp. & D. Rubinoff & FJ872114/FJ949570 \\
\hline $48-52$ & February 2006 & $\begin{array}{l}\text { Tutuila, American } \\
\text { Samoa }\end{array}$ & $\begin{array}{l}\text { Erythrina variegata } \\
\text { orientalis }\end{array}$ & N. Gurr & FJ872114/FJ949570 \\
\hline $\begin{array}{l}54 \\
\text { Quadrastichus } \\
\quad \text { sp. } 1\end{array}$ & June 2006 & $\begin{array}{l}\text { Somerset West, } \\
\text { South Africa }\end{array}$ & Erythrina sp. & $\begin{array}{l}\text { M. Wright, R. } \\
\text { Messing, D. } \\
\text { Rubinoff }\end{array}$ & FJ872116/FJ949568 \\
\hline $\begin{array}{l}58 \\
\text { Quadrastichus } \\
\quad \text { sp. } 2\end{array}$ & June 2006 & $\begin{array}{c}\text { Somerset West, } \\
\text { South Africa }\end{array}$ & Erythrina sp. & $\begin{array}{l}\text { M. Wright, R. } \\
\text { Messing, D. } \\
\text { Rubinoff }\end{array}$ & NA/FJ949569 \\
\hline $\begin{array}{l}82 \\
\text { Quadrastichus } \\
\text { baitensis }\end{array}$ & - & $\begin{array}{l}\text { Dade County, } \\
\text { Homestead, } \\
\text { Florida }\end{array}$ & Pims Palms & R. Duncan & FJ872115/NA \\
\hline $102-106$ & June 2006 & Mangilao, Guam & Erythrina sp. & R. H. Miller & FJ872114/FJ949570 \\
\hline $107-112$ & December 2006 & $\begin{array}{c}\text { Yozo Itoman City, } \\
\text { Okinawa, Japan }\end{array}$ & Erythrina variegata & $\begin{array}{l}\text { N. Uechi (Uechi } \\
\text { et al. 2007) }\end{array}$ & FJ872114/FJ949570 \\
\hline $\begin{array}{l}114 \\
\text { Quadrastichus } \\
\quad \text { sp. } 2\end{array}$ & April 2006 & $\begin{array}{l}\text { Road 40, South } \\
\text { Africa }\end{array}$ & Erythrina latissima & $\begin{array}{l}\text { M. Wright, R. } \\
\text { Messing, D. } \\
\text { Rubinoff }\end{array}$ & FJ872113/FJ949567 \\
\hline $141-146$ & December 2006 & Singapore & Erythrina sp. & R. Messing & FJ872114/FJ949570 \\
\hline TW & - & Taiwan & -1 & $-^{\circ}$ & EF377343/NA \\
\hline SY & - & China & - & - & EF377345/NA \\
\hline $\mathrm{SZ}$ & - & $\begin{array}{l}\text { Shenzen, } \\
\text { Guangdong, } \\
\text { China }\end{array}$ & - & - & EF377346/NA \\
\hline TW & - & $\begin{array}{l}\text { Shenzen, } \\
\text { Guangdong, } \\
\text { China }\end{array}$ & - & - & EF377347/NA \\
\hline $\mathrm{ZH}$ & - & $\begin{array}{l}\text { Shenzen, } \\
\text { Guangdong, } \\
\text { China }\end{array}$ & - & - & EF377348/NA \\
\hline
\end{tabular}

proaches was appropriate due to a complete lack of polymorphism in all invasive populations sampled.

\section{DISCUSSION}

Invasive populations of the erythrina gall wasp have completely defoliated and killed several species of Erythrina trees across a wide range of environments. In the Hawaiian Islands, there are some instances where endemic Erythrina trees appear to have persisted since the invasion, in spite of infestation, but the trees apparently enter a dormant state and produce neither leaves nor seeds, effectively reducing (or minimizing) their ecological interactions in the forest.

Destructive insect invasions are well documented and can progress rapidly (MacLeod et al. 2002, Johnson et al. 2006, Muirhead et al. 2006), but the pace and scale of the erythrina gall wasp invasion is unprecedented and represents one of the fastest and most devastating insect invasions ever recorded. Although unintentional anthropogenic introduction is the most likely mechanism driving the explosive spread of the erythrina gall wasp, human-mediated transport has rarely 


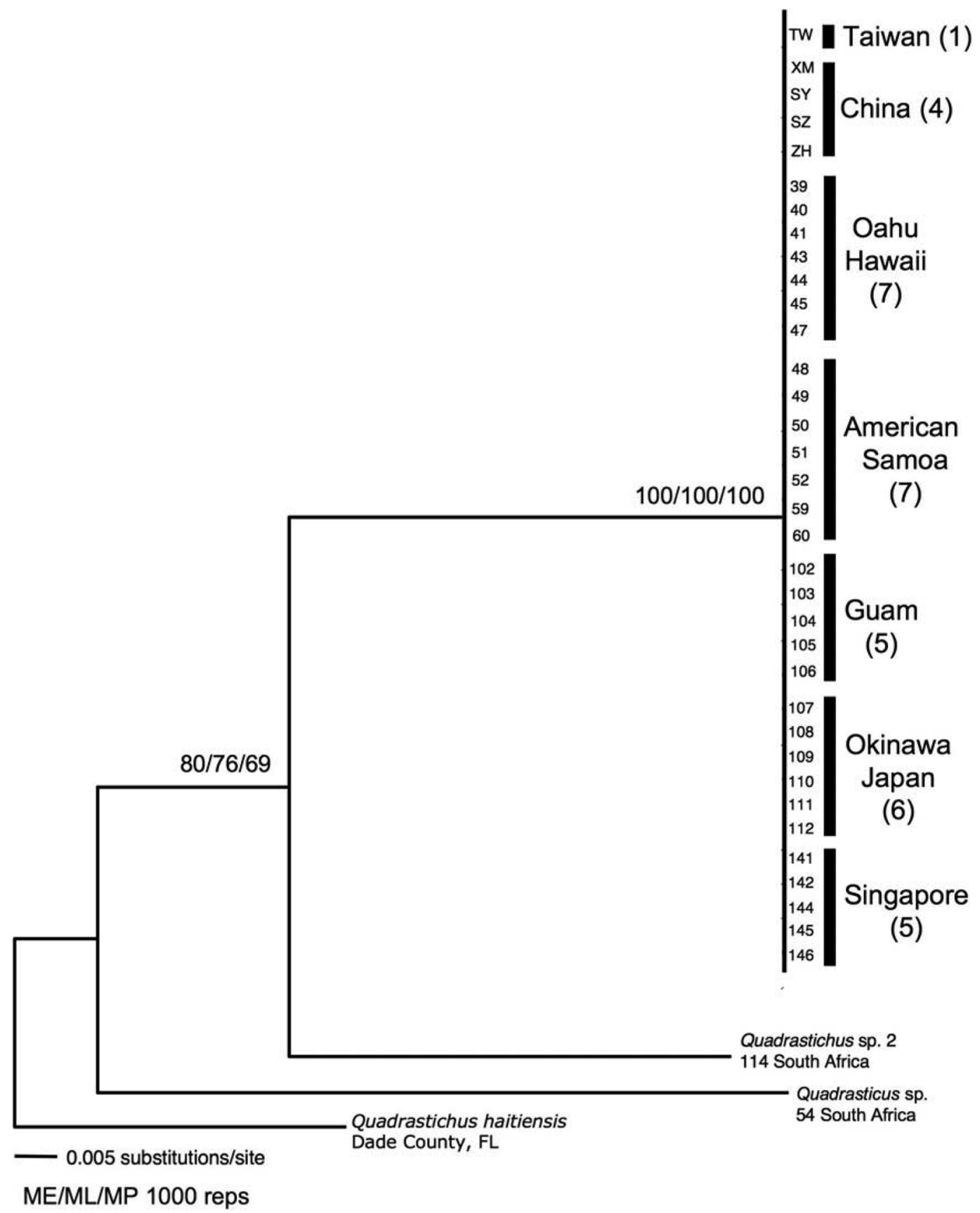

FIGURE 2. Maximum likelihood phylogram with a total of 38 individual wasps, based on 821 base pairs of cytochrome $c$ oxidase I (COI). Bootstrap support is shown as follows: minimum evolution/maximum likelihood/maximum parsimony (ME/ML/MP), based on 1,000 replicates for each optimality criterion. Sequence fragments representing 35 invasive wasp specimens (Quadrastichus erythrinae) from seven sampling localities shared a single haplotype. Outgroups were collected in South Africa and Florida. 


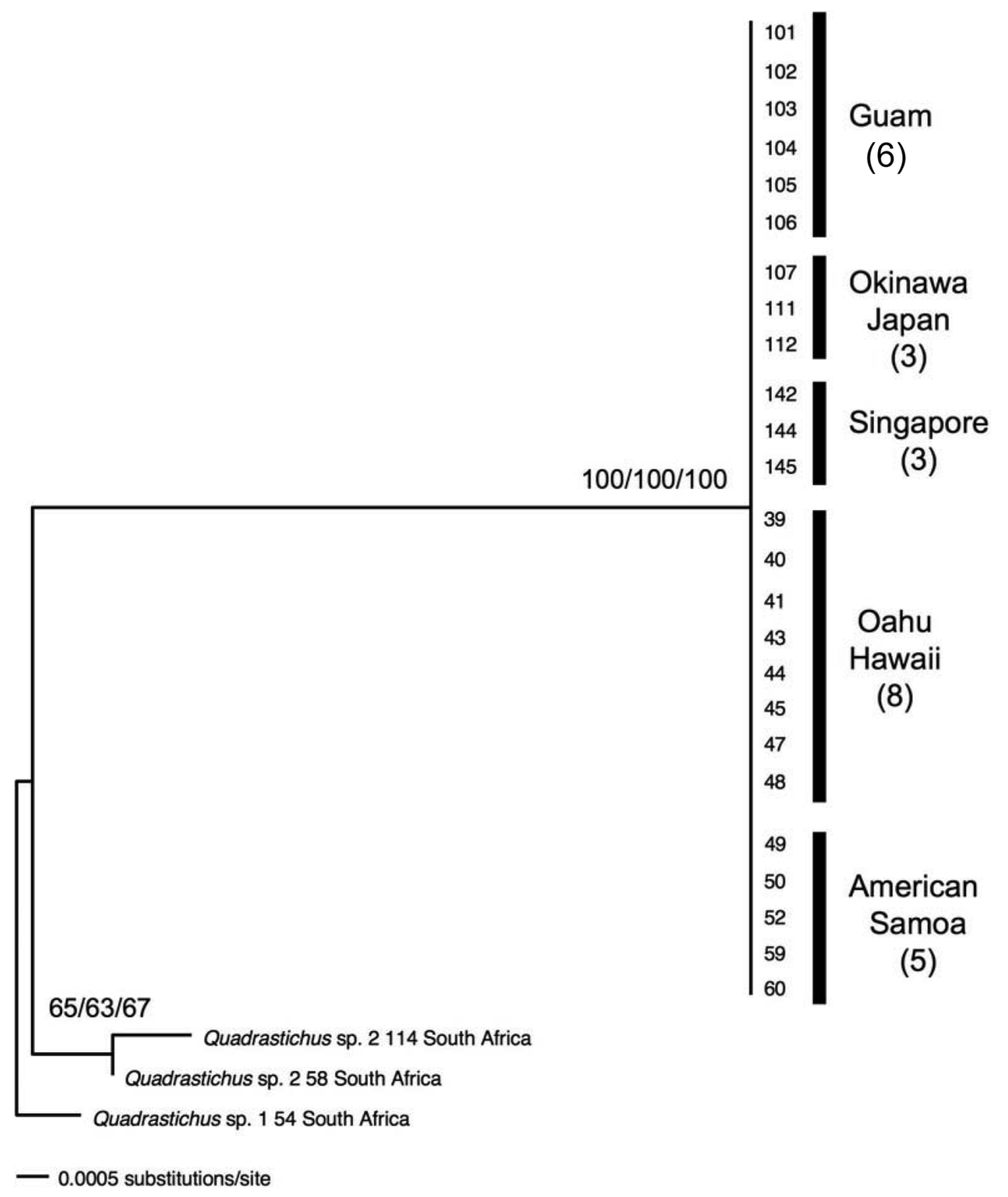

FIGURE 3. Maximum likelihood phylogram based on 802 base pairs of nuclear elongation factor (EF1- $\alpha$ ) for 25 invasive Pacific Quadrastichus erythrinae plus three outgroups. Note that Q. erythrinae nuclear EF1- $\alpha$ from across the Pacific Basin was found to be identical for all ingroup specimens sampled. Bootstrap support shown is based on 1,000 bootstrap replicates as follows: (ME/ML/MP). Outgroups were collected in South Africa. 
been so effectively and rapidly exploited by an invasive species.

The erythrina gall wasp invasion represents not only a single widely dispersed species but also a widely dispersed single mtDNA haplotype coupled with no nuclear DNA diversity in a relatively quickly evolving nuclear gene across the Pacific Basin. A complete lack of detectable genetic variation suggests genetic bottlenecks (e.g., Hedrick 2005) and a recent, rapid expansion from a founding population of limited size or at least low genetic diversity. Genetic monomorphy for nuclear and mtDNA gene sequences from all widespread geographic sampling sites suggests that introductions have occurred from a single panmictic population. Although nonnative $Q$. erythrinae populations currently appear to be thriving in their new environments, the absence of genetic variation raises questions regarding the long-term persistence of invasive populations (Sakai et al. 2001). Knowledge of the provenance of the erythrina gall wasp's explosive invasion may ultimately be informative in terms of determining the mechanism of transport and release; therefore future research to reveal the geographic source of the invasion will be our focus. As globalization and the speed of commerce and transportation increase, additional potentially invasive species that, like the erythrina gall wasp, until now have gone undetected may exacerbate the pace and level of environmental and economic damage sustained by global ecosystems. However through the application of molecular methods to elucidate taxonomic identity and the geographic source of such invasions (Holland 2000), we gain a powerful tool that sheds light on details of introduction mechanisms that will lead to more effective prediction of impacts and methods of prevention for future invaders.

\section{ACKNOWLEDGMENTS}

Mark Schmaedick, Land Grant Program American Samoa Community College; Gerhard Prinsloo and Ottilie Neser, ARC-Plant Protection Research Institute, Pretoria, South Africa; Walter Nagamine, Hawai'i Department of Agriculture; John La Salle, CSIRO,
Canberra, Australia; Jorge Peña, University of Florida; and Nami Uechi, Okinawa Agricultural Research Center, sent specimens or otherwise provided invaluable assistance to this work.

\section{Literature Cited}

Chandler, E. A., J. R. McDowell, and J. E. Graves. 2008. Genetically monomorphic invasive populations of the rapa whelk, $R a$ pana venosa. Mol. Ecol. 17:4079-4091.

Colautti, R. I., M. Manca, M. Viljanen, H. A. M. Ketelaars, H. Burgi, H. J. MacIsaac, and D. D. Heath. 2005. Invasion genetics of the Eurasian spiny waterflea: Evidence for bottlenecks and gene flow using microsatellites. Mol. Ecol. 14:18691879.

Cunningham, C. W. 1997. Is congruence between data partitions a reliable predictor of phylogenetic accuracy? Empirically testing an iterative procedure for choosing among phylogenetic methods. Syst. Biol. 46:464-478

Felsenstein, J. 1985. Confidence limits on phylogenies: An approach using the bootstrap. Evolution 39:783-791.

Gramling, C. 2005. Hawaii's coral trees feel the sting of foreign wasps. Science (Washington, D.C.) 310:1759-1760.

Hassan, M., M. Harmelin-Vivien, and F. Bonhomme. 2003. Lessepsian invasion without bottleneck: Example of two rabbitfish species (Siganus rivulatus and Siganus luridus). J. Exp. Mar. Biol. Ecol. 291:219-232.

Hedrick, P. W. 2005. Genetics of populations. Jones and Bartlett, Sudbury, Massachusetts.

Heu, R. A., D. M. Tsuda, W. T. Nagamine, and T. H. Suh. 2005. New pest advisory no. 05-03. Department of Agriculture, State of Hawai'i, Honolulu.

Holland, B. S. 2000. Genetics of marine bioinvasions. Hydrobiologia 420:63-71.

- 2001. Invasion without a bottleneck: Microsatellite variation in natural and invasive populations of the brown mussel, Perna perna (L.). Mar. Biotech. 3:407-415. Johnson, D. M., A. M. Liebhold, P. C. 
Tobin, and O. Bjoernstad. 2006. Allee effects and pulsed invasion by the gypsy moth. Nature (Lond.) 444:361-363.

Kim, I. K., G. Delvare, and J. La Salle. 2004. A new species of Quadrastichus (Hymenoptera: Eulophidae): A gall-inducing pest on Erytbrina (Fabaceae). J. Hymenop. Res. 13:243-249.

Le Roux, J., A. M. Wieczorek, M. G. Wright, and C. Tran. 2007. Super-genotype: Global monoclonality defies the odds of nature. Public Library of Science ONE 2(7): e590. (DOI: 10.1371/journal.pone .0000590 .)

Li, H. M., H. Xiao, H. Peng, H. Han, and D. Xue. 2006. Potential global range expansion of a new invasive species, the Erythrina gall wasp, Quadrastichus erythrinae Kim (Insecta: Hymenoptera: Eulophidae). Raffles Bull. Zool. 54:229-234.

Lindholm, A. K., F. Breden, H. J. Alexander, W.-K. Chan, S. G. Thakurta, and R. Brooks. 2005. Invasion success and genetic diversity of introduced populations of guppies, Poecilia reticulata, in Australia. Mol. Ecol. 14:3671-3682.

Mabberly, D. J. 1987. The plant-book: A portable dictionary of the higher plants. Cambridge University Press, Cambridge.

MacLeod, A., H. F. Evans, and R. H. A. Baker. 2002. An analysis of pest risk from an Asian longhorn beetle (Anoplophora glabripennis) to hardwood trees in the European community. Crop Prot. 21:635645.

Messing, R. H., S. Noser, and J. Hunkeler. Using host plant relationships to determine the origin of the invasive Erythrina Gall Wasp. Biol. Invasions (in press). Online First: DOI 10.1007/s10530-0089379-y

Muirhead, J. R., B. Leung, C. Overdijk, D. W. Kelly, K. Nandakumar, K. R. Marchant, and H. J. MacIsaac. 2006. Modelling local and long-distance dispersal of invasive emerald ash borer, Agrilus planipennis (Co- leoptera), in North America. Divers. Distrib. 12:71-79.

Rubinoff, D., and B. S. Holland. 2005. Between two extremes: Mitochondrial DNA is neither the panacea nor the nemesis of phylogenetics and systematic inference. Syst. Biol. 54:952-960.

Sakai, A. K., F. W. Allendorf, J. S. Holt, D. M. Lodge, J. Molofsky, K. A. With, S. Baughman, R. J. Cabin, J. E. Cohen, N. C. Ellstrand, D. E. McCauley, P. O'Neil, I. M. Parker, J. N. Thompson, and S. G. Weller. 2001. The population biology of invasive species. Annu. Rev. Ecol. Syst. 32:305-332.

Schmaedick, M., M. Tuionoula, and S. Lal. 2006. Erythrina gall wasp (Quadrastichus erythrinae). Secretariat of the Pacific Community, Land Resource Division. Pest Focus, January 2006.

Tung, G.-S., L.-W. Wu, Y.-S. Yang, C.-C. Hsu, and M.-M. Yang. 2009. Genetic differentiation of the eulophid wasp Quadrastichus erythrinae Kim (Hymenoptera: Eulophidae) from various Erythrina hosts based on mitochondrial and nuclear genes. Formosan Entomol. 28:305-313.

Tsutsui, N. D., and A. V. Suarez. 2003. The colony structure and population biology of invasive ants. Conserv. Biol. 17:48-58.

Uechi, N., T. Uesato, and J. Yukawa. 2007. Detection of an invasive gall-inducing pest, Quadrastichus erythrinae (Hymenoptera: Eulophidae), causing damage to Erythrina variegata L. (Fabaceae) in Okinawa Prefecture, Japan. Entomol. Sci. 10:209-212.

Wagner, W. L., D. R. Herbst, and S. H. Sohmer. 1990. Manual of the flowering plants of Hawai'i. University of Hawai'i Press, Bishop Museum Press, Honolulu.

Yang, M. M., G. S. Tung, J. LaSalle, and M. L. Wu. 2004. Outbreak of erythrina gall wasp (Hymenoptera: Eulophidae) on Erythrina spp. (Fabaceae) in Taiwan. Plant Prot. Bull. 46:391-396. 
